\title{
The establishment of a chemically defined serum-free culture system for human dental pulp stem cells
}

\author{
Jingyi Xiao ${ }^{1,2,4^{\dagger}}$, Dawei Yang ${ }^{1,5 \dagger}$, Qiwen $\mathrm{Li}^{1}$, Weidong Tian ${ }^{1,2,3^{*}}$ and Weihua Guo $1,24^{*}$
}

\begin{abstract}
Background: The concept of establishing a dental stem cell (DSC) bank for oral and maxillofacial regeneration has become of great interest but it remains at a primitive stage. The routine application of serum-containing conditions for human DSC (hDSC) culture is in great controversy considering that the animal-originated serum can cause serious ethical concerns and lead to increasingly irrelevant variables, errors, and poor repeatability of experiment results. Thus, this study aimed to establish a safe, stable and efficient hDSC serumfree culturing system for future DSC bank usage.

Methods: Dental pulp stem cells (DPSCs) from human permanent tooth pulp were isolated, expanded, passaged, and divided into two groups according to their culture conditions: group 1 was the serumcontaining medium (SCM) group; and group 2 was the serum-free Essential 8 medium (E8) group. DPSCs were characterized first, followed by cell proliferation, pluripotency, and migration study in SCM and E8 medium.
\end{abstract}

Results: Human DPSCS (hDPSCs) in E8 medium demonstrated greater proliferation, pluripotency, migration ability and less apoptosis. hDPSCs could be successfully induced to the adipogenic, osteogenic, neurogenic, and chondrogenic lineages in E8 group. Real-time polymerase chain reaction indicated that the expression of PPAR- $\gamma$, RUNX2, OCN and MAP-2 was higher in E8 group.

Conclusions: Compared with serum-containing medium, E8 medium exhitibed higher ability in maintaining the cell proliferation, pluripotency, migration, and stability. This new serum-free culture environment might be applicable for hDSC culture in the future.

Keywords: Essential 8 Medium, Dental pulp stem cells, Serum-free culture, Dental stem cell bank

\section{Background}

Human pluripotent stem cells (hPSCs) are clonogenic cells capable of self-renewal and multilineage differentiation. Over the past decades, hPSCs have shown tremendous potential for regenerative medicine, assisted reproductive technologies, and cell therapeutics [1]. Recently, Dever et al. [2] presented a CRISPER/Cas9 gene-editing system with homologous recombination at the HBB gene in hematopoietic stem cells and achieved $90 \%$ targeted integration of purified hematopoietic stem

\footnotetext{
* Correspondence: drtwd@sina.com; guoweihua943019@163.com

${ }^{\dagger}$ Jingyi Xiao and Dawei Yang contributed equally to this work.

${ }^{1}$ State Key Laboratory of Oral Diseases \& National Clinical Research Center for Oral Diseases \& National Engineering, Chengdu, China

Full list of author information is available at the end of the article
}

and progenitor cells. By sorting fetal human pancreatic $\alpha, \beta$, and $\delta$ cells by staining for certain hormones, Blodgett et al. [3] demonstrated extraordinarily high levels of mRNA expression which might pave the way for new strategies for type 1 and type 2 diabetes treatment. Stem cells can also be applied for chronically injured organs. Karantalis and Hare [4] summarized the biology of mesenchymal stem cells and reviewed their wide utilization in cardiac tissue repair and regeneration therapy. Despite the tremendous achievements made over these decades, challenges still exist for taking clinical application of hPSCs to an industrialized scale and pharmaceutical grade production level [5], such as shortages of human stem cells available for research use [1], a

(C) The Author(s). 2018 Open Access This article is distributed under the terms of the Creative Commons Attribution 4.0 International License (http://creativecommons.org/licenses/by/4.0/), which permits unrestricted use, distribution, and 
low perfect histocompatibility match rate between potential recipients and transplant donors [6], and the lack of understanding of the immune response towards the majority of stem cells [7]. Lack of appropriate cryopreservation techniques and recovery methods also contribute to the barrier to the wide utilization of hPSCs [8]. Despite all the obstacles described above, the biggest concern is the culture condition.

Over the past decade, methods for hPSC culture have evolved rapidly to meet the urgent needs of drug discovery and regenerative medicine; however, many problems still need to be resolved, including the lack of specific applications of universally agreed standardized protocols and impurity or heterogeneity of cells [9]. Traditionally, the medium has included serum of either animal or human origin that was added for cell expansion. However, serum of human origin has raised ethical issues and there is a limited amount of collected human serum; therefore, culture medium with added products of animal origin, such as fetal bovine serum (FBS), has become a routine protocol. However, increasing evidence has indicated that FBS is a controversial ingredient owing to its risk of transmitting prion, zoonotic, or viral infections, and the xenogeneic compounds can trigger host immune responses, which are a potential and significant hazard. Another important concern is the batch-to-batch variety of the quality and protein concentration [10-12]. The continuous maintenance of undifferentiated stem cells over the long periods of culture is also essential [13]. Related research, including multiple culturing methods and ingredients, are emerging for the establishment of serum-free medium (SFM). The first attempt at culturing stem cells without using animal products dates back to 1976 when Hayashi and Sato [14] mixed four kinds of hormones (T3, TRH, transferrin, PTH) for stem cell incubation. Hirata et al. [15] demonstrated the sustained proliferation and expression of selected stem cell markers after culturing mouse DPSCs in serum-free media supplemented with a variety of growth factors. Bonnamain et al. [16] also reported successful expansion of human stem cells in a chemically defined serum-free culture medium with added growth factors. In the meantime, discoveries of signal pathways and multiple factor mechanisms in serum-free medium are showing steady progress, and a number of genes connected with the response have been unraveled, contributing to the use of hPSCs as engineering tools for therapeutic purposes [17-21].

Dental pulp stem cells (DPSCs) were firstly described as stem cells by Mooney et al. [22] in 1996. Gronthos and colleagues [23] reported the isolation and characterization of a stem cell population within the dental pulp. Because of the positive expressions of mesenchymal stem cell
(MSC) markers such as STRO-1, CD13, CD24, Oct4, Nanog, and $\beta 2$ integrin, the strong proliferation, self-renewal, and multiple differentiation ability $[15,24$, 25], and easy access and convenient reservation [26], it is feasible to expect their application for dental regeneration, hard tissue engineering, and bio-root regeneration [27].

As dental tissues are an easily available source and the isolation of dental stem cells (DSCs) is a relatively easy and straightforward procedure [28], the concept of establishing a DSC bank has arisen. However, compared with the umbilical cord blood stem cell bank that has been well established for decades, the DSC bank is still at a very primitive stage. The term "tooth bank" was first raised in 1966 [29], but it was not until 2004 that the first commercial tooth bank was established at the National Hiroshima University in Japan as a venture company [30].

The culturing environment also plays a key role in the continuous maintenance of undifferentiated human DPSCs (hDPSCs) over the long term. However, most of the research and discoveries concerning media aimed at human embryonic stem cells (hESCs), and suitable SFM for hESCs might not be applicable for hDPSCs. Thus, despite all the effort and research devoted to this field, there is still no protocol for a well-defined, serum-free culturing condition for hDPSCs to maintain their proliferation capacity and differentiation potential.

E8 medium is a chemically defined, albumin-free medium created by the laboratory of James Thomson [31] designed for induced pluripotent stem cell (iPSC) culturing for both clinical applications and research use. E8 is a chemically defined medium containing Dulbecco's modified Eagle's medium (DMEM)/F12, $64 \mathrm{mg} /$ 1 L-ascorbic acid-2-phosphate magnesium, $14 \mu \mathrm{g} / \mathrm{l}$ sodium selenium, $100 \mu \mathrm{g} / \mathrm{l}$ fibroblast growth factor (FGF)2, $19.4 \mathrm{mg} / \mathrm{l}$ insulin, $543 \mathrm{mg} / \mathrm{l} \mathrm{NaHCO}_{3}$, and $10.7 \mathrm{mg} / \mathrm{l}$ transferrin, $2 \mu \mathrm{g} / \mathrm{l}$ transforming growth factor (TGF) $\beta 1$ or $100 \mu \mathrm{g} / \mathrm{l}$ Nodal. Osmolarity of the medium was adjusted to $340 \mathrm{mOsm}$ at $\mathrm{pH}$ 7.4, which simplified the quality control and reduced the financial cost. This simplified medium also gives a cleaner background for experiments on cell death, cell differentiation, and self-renewal, and significantly improves reprogramming efficiency. Thus far, E8 is a relatively mature medium and, furthermore, some components in E8 such as FGF2, TGFß1, and insulin have been shown to be essential for the maintenance and growth of hDPSCs. This makes its use for analyzing the culture conditions of hDPSCs very practical.

In the present study, we expanded hDPSCs in vitro under E8 medium conditions and conventional serum-containing medium (SCM) as a control, and investigated the differences in cell characteristics, cell proliferation capacity, and cell pluripotency potential. 


\section{Methods}

\section{Cell culture in E8 and SCM}

Extracted deciduous and wisdom teeth were obtained and checked for the viability of their pulp. The extracted teeth surfaces were cleaned and then cut up by sterilized hammers and cracked open to extract the dental pulp. Afterwards, the pulp was digested in a solution of $3 \mathrm{mg} / \mathrm{ml}$ collagenase type I for $0.5 \mathrm{~h}$ at $37{ }^{\circ} \mathrm{C}$, and then treated by trypsin for $2 \mathrm{~min}$. Cell suspensions were seeded in culture plates (Thermo, USA) and cultured in DMEM with $10 \%$ FBS (Hyclone, USA). After cells reached a concentration of $80 \%$, they were cultured under separate conditions: in the E8 group, the cell suspensions were incubated at a cell density of $2 \times 10^{5}$ cells per culture plate in albumin-free E8 culture medium (Stemcell, USA) containing chemically defined and concentration-determined multiple factors; in the SCM group, the cell suspensions were plated at the same cell density in normal medium containing DMEM and 5\% FBS as a control. Passage (P)3 cells were employed for the following analyses.

\section{Colony-forming unit fibroblast (CFU-F) analysis}

P3 hDPSCs were digested, suspended, and incubated at a density of $10^{4}$ cells in $12.5-\mathrm{cm}$ plates. The culture medium was replaced every 3 days. Cells were fixed and labeled with toluidine blue for $40 \mathrm{~min}$ at room temperature at 10 days, and a random circle with a diameter of $30 \mathrm{~mm}$ was chosen from each plate and the formed colonies within the circles were counted (growing cells with a spindle shape, and colony with $>50$ cells).

\section{Flow cytometric characteristic analysis}

Approximately $5 \times 10^{5}$ cells were incubated for flow cytometric analysis for $1 \mathrm{~h}$ at $4{ }^{\circ} \mathrm{C}$ with anti-CD29 (555,443, BD, 1:1000, phycoerythrin (PE)), CD31 (303,104, Biolegend, 1:1000, fluorescein isothiocyanate (FITC)), CD44 (555,478, BD, 1:1000, FITC), CD45 (555,482, BD, 1:1000, FITC), CD73 (550,257, BD, 1:1000, PE), CD90 (555,595, BD, 1:1000, FITC), CD105 (561,443, BD, 1:1000, FITC), and CD166 (559,263, BD, 1:1000, PE). FITC-conjugated or PE-conjugated isotype-matched immunoglobulins were used to examine nonspecific staining. Goat anti-mouse and goat anti-rat IgG-FITC (Santa Cruz) were applied as the secondary agent. FACS Caliber (Becton-Dickinson, CA, USA) was used for the analysis.

\section{Flow cytometric cell cycle analysis}

Before flow cytometric cell cycle analysis, both E8 and SCM groups were starved in DMEM culture medium without FBS for at least $24 \mathrm{~h}$. Cells were fixed with ethanol and dyed with propidium iodide (PI). Data were obtained through the FACS Caliber (Becton-Dickinson, CA, USA) and analyzed by the cell number percentages at different stages on the PI fluorescence histogram using FlowJo software.

\section{Flow cytometric cell apoptosis analysis}

Cells $(10 \mathrm{ml})$ were obtained at a density of $5 \times 10^{5}$ cells $/ \mathrm{ml}$ and centrifuged for $5 \mathrm{~min}$ and washed twice. Sedimentations were incubated for $20 \mathrm{~min}$ at $4{ }^{\circ} \mathrm{C}$. The results were analyzed with FACS Caliber (Becton-Dickinson, CA, USA) at an excitation wavelength of $488 \mathrm{~nm} ; 515 \mathrm{~nm}$ absorbance was used to detect FITC fluorescence and $560 \mathrm{~nm}$ absorbance was used to detect PI fluorescence.

\section{Cell proliferation analysis by CCK-8}

Cells were digested and plated into 96-well plates (Thermo, USA) at a density of $2 \times 10^{3}$ cells/well with culture conditions applied. After 24 h, 48 h, 72 h, 96 h, and $120 \mathrm{~h}$ of incubation, these cells were tested according to the Cell Counting Kit-8 (CCK-8, Dojindo Laboratories, Kumamoto, Japan) procedure. Averaged data were used to produce CCK-8 growing curves for visual observation.

\section{Bromodeoxyuridine (BrdU) cell proliferation assay}

hDPSCs were incubated with $30 \mu \mathrm{l}$ BrdU (Sigma, Germany) for $48 \mathrm{~h}$. The solutions were then dispersed, the cells were fixed, DNA was denatured, and anti-BrdU antibody (MAB3424, Millipore, USA) was applied. The secondary antibody used was Alexa fluor 488 goat anti-mouse (A11001, Invitrogen, USA). Fluorescence microscopy was used to view the stained cells.

\section{Immunofluorescence}

hDPSCs were subcultured $\left(2 \times 10^{5}\right.$ cells/well $)$ into six-chamber slides (Thermo, USA), fixed in $4 \%$ paraformaldehyde for $0.5 \mathrm{~h}$, perforated with $0.5 \%$ Triton $\mathrm{X}-100$ for $0.5 \mathrm{~h}$, and then treated with $1 \%$ bovine serum albumin (BSA) for $1 \mathrm{~h}$. Anti-OCT4 (D121072, Shenggong, China), anti-SOX2 (ab97959, Abcam, UK), anti-NANOG (sc-33,760, Santa Cruz, USA), anti-DMP1 (sc-6551, Santa Cruz, USA), anti-DSP1-H (sc-73,632. Santa Cruz, USA), anti-OCN (AP2002a x, Zen, China), anti-OPN (ab8448, Abcam, UK), anti-RUNX2 (ab76956, Abcam, UK), anti-BMP2 (sc-23,299, Santa Cruz, USA), and anti-P53 (ab26, Abcam, UK), and the secondary antibodies donkey anti-goat immunoglobulin G (A21432, Invitrogen, USA), Alexa fluor 555-conjugated goat anti-mouse immunoglobulin G (A21422, Invitrogen, USA), and goat anti-rabbit immunoglobulin G (A21428, Invitrogen, USA) were applied. Nuclei were stained with DAPI. The stained cells were observed under an Olympus inverted microscope. 


\section{Western blot}

Cells were digested with the Total Protein Extraction Kit (KeyGene, China) and centrifuged to collect cell supernatants. A BCA assay was used to determine the protein concentration. Proteins $(30 \mu \mathrm{g})$ were separated on 10\% sodium dodecyl sulphate-polyacrylamide gel and transferred to a PVDF membrane, and then blocked with 5\% nonfat dry milk dissolved in TBST (Tris-buffered saline, 0.1\% Tween-20). The primary antibodies anti-DMP1, anti-DSPP, anti-OPN, anti-ALP, anti-RUNX2, and GAPDH were used at dilutions of 1:1000 for $2 \mathrm{~h}$ at room temperature, and then washed with TBST twice on a TS rocker. Secondary antibodies were applied in the same way. Bands were monitored with an electrochemiluminescence system (GE, USA).

\section{Multidifferentiation in hDPSCs}

hDPSCs were seeded at a density of $1 \times 10^{5}$ into six-well plates with $80 \%$ concentration. The cells were separately cultured in osteogenic-inducing medium (100 nM dexamethasone (Sigma, USA), $50 \mathrm{mg} / \mathrm{ml}$ ascorbic acid (Sigma, USA), 10\% FBS, 5 mM L-glycerophosphate (Sigma, USA)) for 15 days, adipogenic medium (alpha-minimum essential medium (MEM) supplemented with $2 \mathrm{mM}$ insulin (Sigma, USA), 10\% FBS, $10 \mathrm{nM}$ dexamethasone (Sigma, USA), and $0.5 \mathrm{mM}$ isobutylmethylxanthine (IBMX; Sigma, USA)) for 15 days, chondrogenic medium $(6.25 \mathrm{mg} / \mathrm{ml}$ insulin, $50 \mu \mathrm{g} /$ $\mathrm{ml}$ dexamethasone, $50 \mathrm{mg} / \mathrm{ml} \mathrm{ITS} \mathrm{+} \mathrm{Premix,} 10 \mathrm{ng} / \mathrm{ml}$ TGF- $\beta 1,100 \mu \mathrm{g} / \mathrm{ml}$ pyruvate, $40 \mu \mathrm{g} / \mathrm{ml}$ valine, $100 \mu \mathrm{g} / \mathrm{ml}$ penicillin, $100 \mu \mathrm{g} / \mathrm{ml}$ streptomycin, 10\% FBS, and DMEM high-sugar culture medium) for 15 days, and neurogenic medium (200 mM butylated hydroxyanisole (Sigma, USA), 2\% dimethyl sulfoxide (DMSO), $10 \mathrm{mM}$ forskolin (Sigma, USA), $25 \mathrm{mM} \mathrm{KCl} \mathrm{(Kelong,} \mathrm{China),} 1 \mathrm{mM}$ hydroxycortisone (Sigma, USA), $5 \mathrm{mg} / \mathrm{ml}$ insulin (Gibco, USA), $2 \mathrm{mM}$ valporic acid (Sigma, USA) and $2 \mathrm{mM}$ L-glutamine (Sigma, USA)) for $3 \mathrm{~h}$. Afterwards, neurogenic-induced cells were observed with immunocytofluorescence for expression levels of the neural cell marker bIII-tubulin (Abcam, USA) and chondrogenic-induced cells with anti-col II (ab37,412, Abcam, UK). Other cells were fixed in $4 \%$ paraformaldehyde for $10 \mathrm{~min}$ and incubated in $0.1 \%$ alizarin red solution (Sigma, USA) in TriseHCl (pH 8.3) for osteogenic differentiation detection, or stained with $0.3 \%$ Oil Red O (Sigma, USA) solution for adipogenic differentiation detection.
RNA extraction and real-time polymerase chain reaction (PCR)

Osteogenic, adipogenic, and neurogenic differentiationinduced P3 hDPSCs were chosen for the real time-PCR detection. All groups were induced for 7 days (except for neurogenic differentiation for $3 \mathrm{~h}$ ) and then cultured for 7 days. RNAiso Plus (Takara, Japan) was used to extract total RNA from the cells in accordance with the manufacturer's instructions. The complementary DNA (cDNA) synthesis was processed by the Revert Aid First Stand cDNA Synthesis Kit (Thermo Scientific, USA). The primer pairs for RUNX2, OCN, PPAR, MAP-2, and GAPDH are shown in Table 1.

\section{Cell migration capacity analysis}

hDPSCs were digested and centrifuged at $80 \%$ confluence. Sedimentations were suspended with DMEM. Cell density was adjusted to $3 \times 10^{5} / \mathrm{ml}$ and culturing medium was added into $6.5-\mathrm{mm}$ transwell 24 -well plates with a sterile $8.0-\mu \mathrm{m}$ pore polycarbonate membrane (Costar, USA) at a volume of $600 \mu \mathrm{l}$ for each well with culture conditions applied. Cells were seeded into the upper wells with $120 \mu \mathrm{l}$ DMEM. After $12 \mathrm{~h}$ and $24 \mathrm{~h}$ of incubation, cells in the upper wells were removed and lower well cells were washed twice in phosphate-buffered saline (PBS) and stained with crystal violet for $10 \mathrm{~min}$ after being fixed in 4\% paraformaldehyde for $15 \mathrm{~min}$.

Marker pens were applied to draw straight lines on the back of the six-well plates at a distance of $0.5 \mathrm{~cm}$. Cells were seeded into the six-well plates at a density of $1 \times$ $10^{5} / \mathrm{ml}$ with culture conditions applied. After 3 days of incubation, pipette tips were used to scratch according to the marked line. Samples were inspected at $0 \mathrm{~h}, 24 \mathrm{~h}$, and $48 \mathrm{~h}$.

\section{Statistical analysis}

Results are presented as the means \pm standard deviations. Statistical analysis was performed using Students' paired $t$ test. Statistical significance was accepted at $p<0.05$.

\section{Results}

\section{Changes in cell morphology}

Cells cultured in SCM proliferated sparsely in a single layer and demonstrated typical spindle and polygonal

Table 1 Polymerase chain reaction primer design

\begin{tabular}{lll}
\hline Gene & Forward primer $\left(5^{\prime}-3^{\prime}\right)$ & Reverse primer $\left(5^{\prime}-3^{\prime}\right)$ \\
\hline Runx2 & GAAATGCCTCTGCTGTTATGAA & CCGTTATGGTCAAAGTGAAACTC \\
OCN & CCTCTCTCTGCTCACTCTGCTG & ACCTTACTGCCCTCCTGCTTG \\
PPARY & TCCGAAGAACCATCCGATTGAA & CCACAGCAAGGCACTTCTGA \\
MAP-2 & GTGAGTGCAGATGCTGAGGT & TGGCAATGGGACTGTGTACT \\
GAPDH & TATGACTCTACCCACGGCAAG & TACTCAGCACCAGCATCACC \\
\hline
\end{tabular}


shapes. On the other hand, cells cultured in E8 tended to grow in close contact with one another and demonstrated more homogeneous shapes (Fig. 1). Cells cultured in $\mathrm{E} 8$ for $48 \mathrm{~h}$ and $96 \mathrm{~h}$ did not present differences in cell morphology.

\section{Identification of MSC surface markers}

Both the SCM group and the E8 group expressed high levels of CD29, CD44, CD73, CD90, and CD166, and did not express CD31, CD45, or CD105 (Fig. 2), which agreed with MSC surface marker expression and proved that the majority of these cells were DPSCs.

\section{E8 can promote hDPSC proliferation}

CFU-F results indicated that, at 10 days, a significant difference was observed between E8 and SCM (Fig. 3a-c) $(p<0.01)$. BrdU assay showed that, at $48 \mathrm{~h}$, E8-cultured hDPSCs exhibited a stronger proliferation capacity with higher fluorescence labeling rate than culture with SCM (Fig. 3d-f) $(p<0.01)$. We used CCK-8 to analyze hDPSCs cultured for $4 \mathrm{~h}, 24 \mathrm{~h}, 48 \mathrm{~h}, 72 \mathrm{~h}, 96 \mathrm{~h}, 120 \mathrm{~h}$,
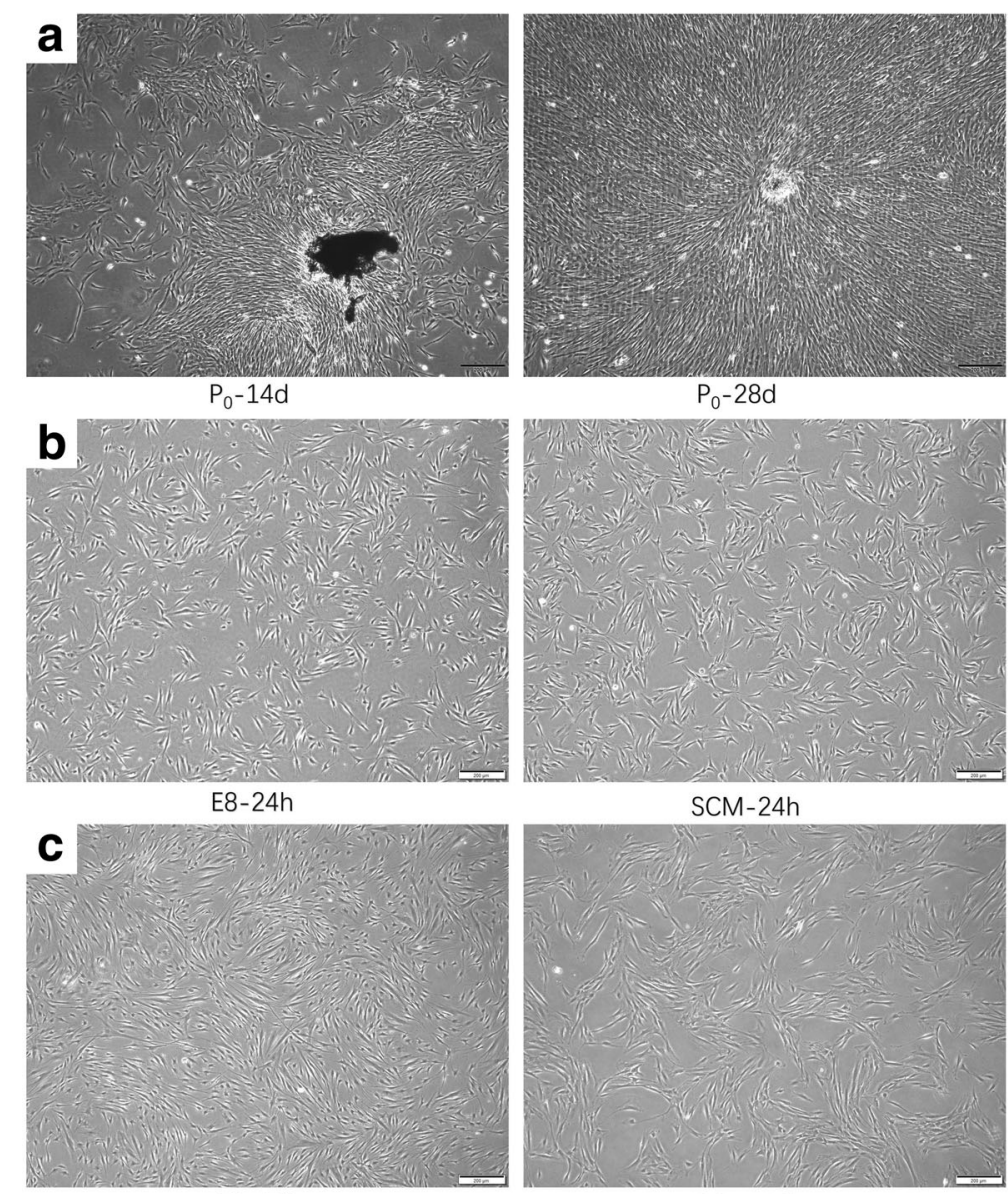

E8-48h

SCM-48h

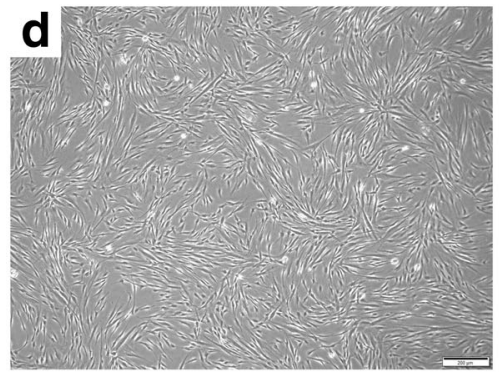

E8-96h

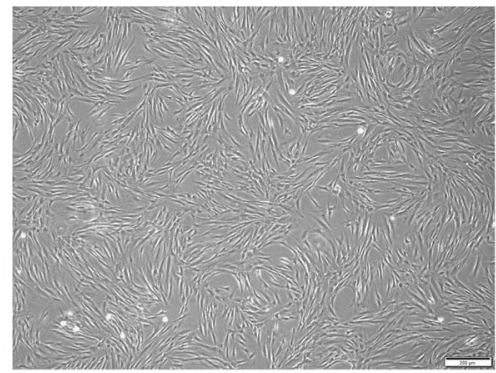

SCM-96h

Fig. 1 Cell morphology. a Images of primary culture for $14 \mathrm{~d}$ and $28 \mathrm{~d}$. b-d Differences in cell morphology after culture in E8 (left) and serumcontaining medium (right; SCM; DMEM + 5\% FBS) for b 24 h, c 48 h, and d 96 h 


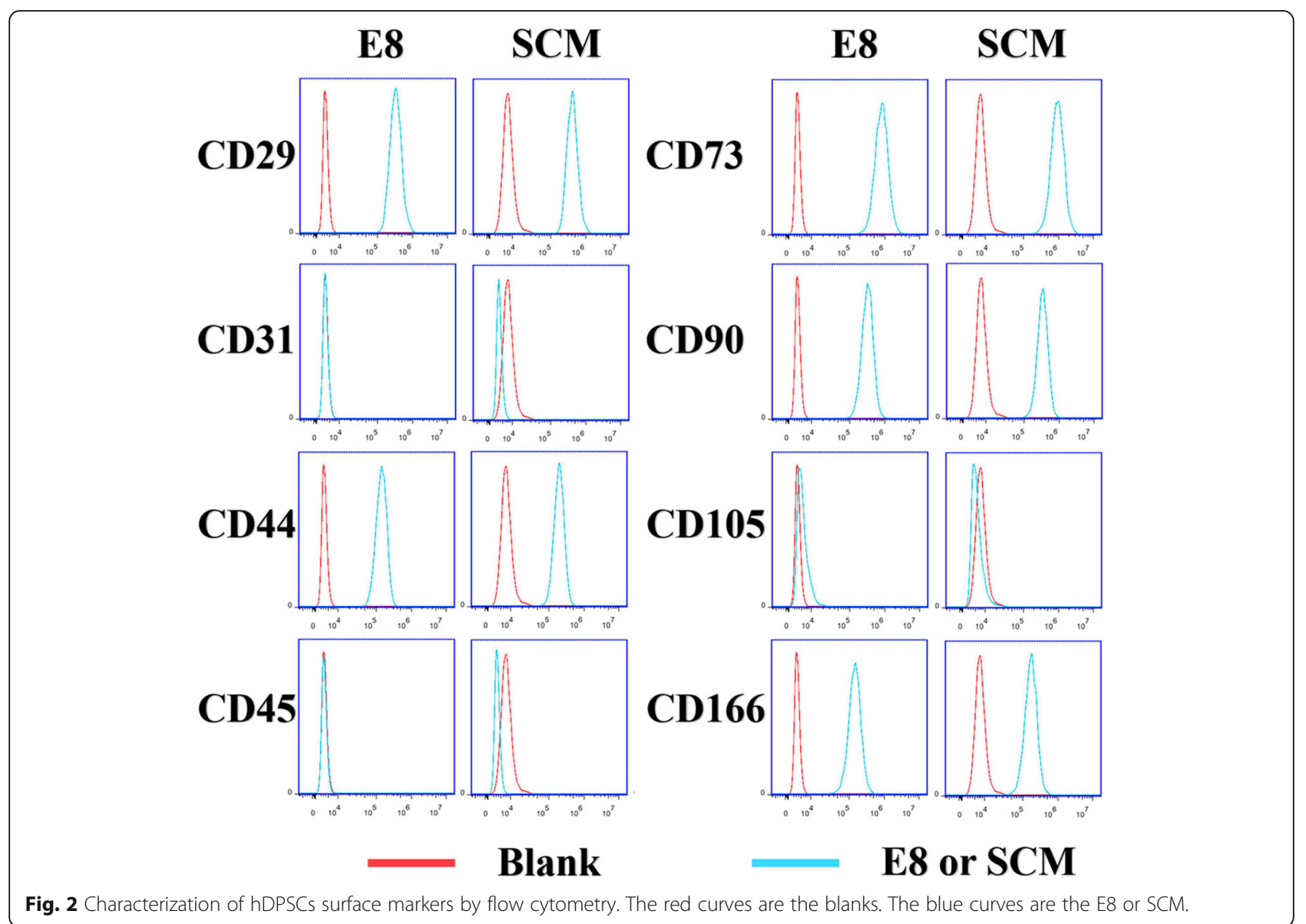

and $144 \mathrm{~h}$. Data were obtained as average optical density (OD) values and a CCK-8 growth curve was produced (Fig. 3i) Statistical differences were observed between the E8 group and the SCM group at $24 \mathrm{~h}, 48 \mathrm{~h}, 72 \mathrm{~h}$, and $96 \mathrm{~h}(p<0.01)$.

To study why cell proliferation rate differed between E8 and SCM, we analyzed the cell cycle and apoptosis. Images captured by FlowJo software are presented in Fig. 3g. A significant difference was seen, and E8-cultured hDPSCs possessed fewer cell numbers in the G0/G1 ratio $(p<0.01)$ and higher numbers in the $\mathrm{S}$ ratio $(p<0.01)$ and $\mathrm{G} 2 / \mathrm{M}$ ratio $(p<$ 0.01 ) (Fig. 3h). Flow cytometry was used to analyze apoptosis, and the resultshowed difference between the SCM group and the E8 group regarding early $(p<0.05)$, late $(p<0.01)$, and total apoptosis $(\mathrm{p}<$ 0.01 ) (Fig. 4c). Images processed by FlowJo software are also presented in Fig. 4a. Western blotting and immunofluorescence also demonstrated that the apoptosis rate of hDPSCs in E8 group was lower than that in SCM group (Figs. 4b and 5c). Altogether, it can be deduced that the E8 medium increased the hDPSC proliferation rate through accelerating the cell splitting speed and decreasing the cell apoptosis rate.
Expression of stem cell markers by immunofluorescence and Western blotting

Immunofluorescence was applied to analyze OCT4, SOX2, and NANOG for cell pluripotency, and a relatively low expression was obeserved in both E8 and SCM (Fig. 5a). Odontogenesis-related markers DMP1 and DSP1-H, also showed low expression (Fig. 5b). OCN, OPN, and RUNX2, analyzed for the osteogenic tendency, demonstrated high levels of expression, but BMP2 expression was lower in both groups (Fig. 5d). Western blot results also showed low expression in the odontogenic markers DMP1 and DSPP for both groups. For the osteogenic markers, Western blot results of OPN and RUNX2 showed expression at high levels, and ALP was expressed at low levels (Fig. 4d).

\section{Induced hDPSC differentiation analysis}

hDPSCs under E8 and SCM conditions at P3 were incubated and induced under different cultural conditions. In the osteogenic-inducing group at 15 days, hDPSCs formed mineralized nodules by alizarin red staining (Fig. 6a). After culture under adipogenic conditions for 15 days, hDPSCs formed lipid droplets when stained with Oil Red O (Fig. 6b). hDPSCs also exhibited 


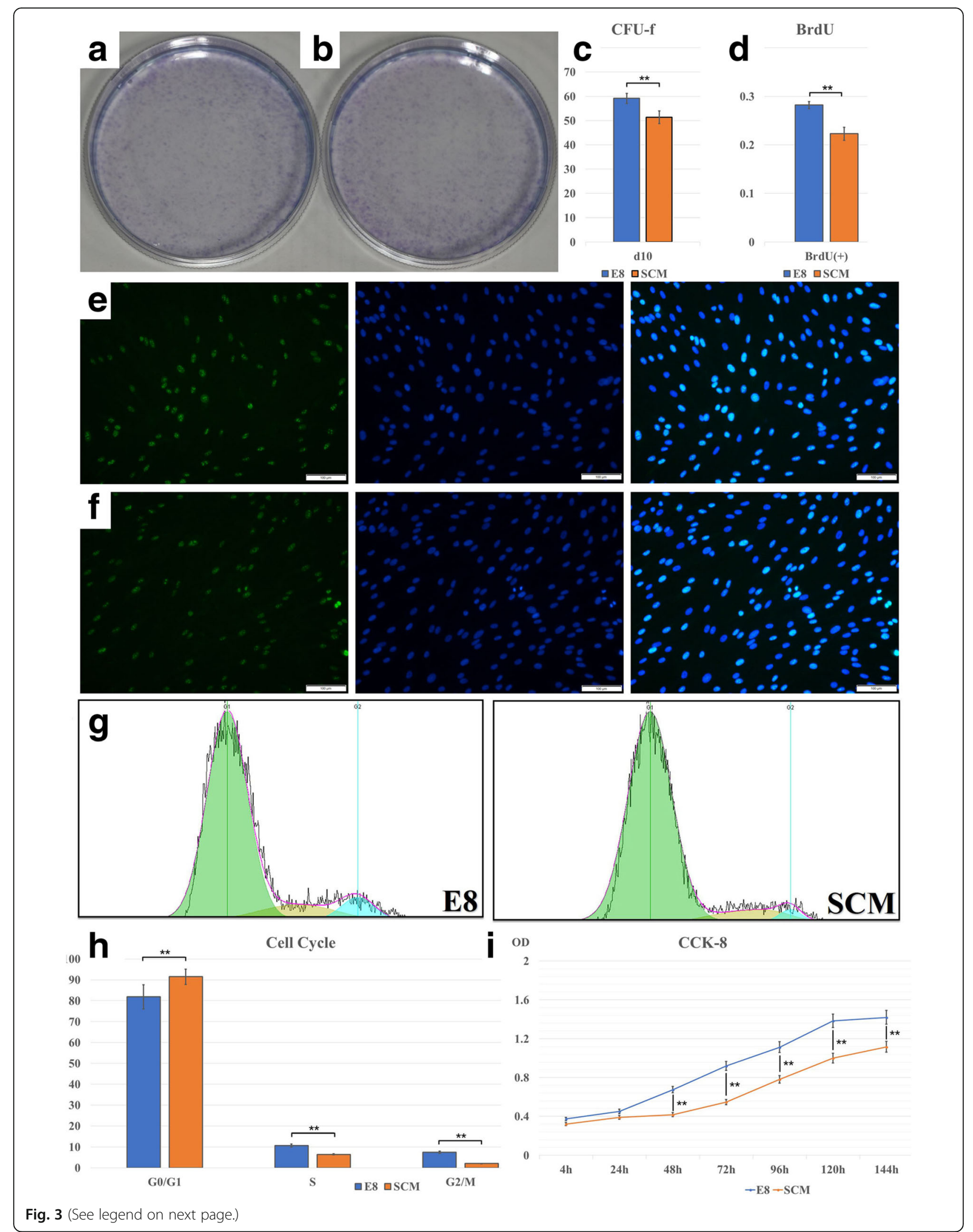


(See figure on previous page.)

Fig. 3 Colony-forming unit fibroblasts (CFU-F) of a serum-containing medium (SCM) and $\mathbf{b}$ E8. Statistical analysis of $\mathbf{c}$ CFU-F comparison ( $n=5$ ) and $\mathbf{d}$ bromodeoxyuridine (BrdU) proliferation assay $(n=5)$. BrdU fluorescence of hDPSCs in e E8 and $\mathbf{f}$ SCM. $\mathbf{g}$ Cell cycles were analyzed with Flowjo software. $\mathbf{h}$ Statistical analysis of the cell cycle $(n=5)$. $\mathbf{i}$ Cell proliferation analysis using the CCK-8 assay. The different optical density (OD) values are presented at $4 \mathrm{~h}, 24 \mathrm{~h}, 48 \mathrm{~h}, 72 \mathrm{~h}, 96 \mathrm{~h}, 120 \mathrm{~h}$, and 6 days $(n=10) .{ }^{*} p<0.05,{ }^{* *} p<0.01$

green fluorescence under neurogenic and chondrogenic induction (Fig. 6c, d). Real-time PCR was used to further quantity the detection of the multidifferentiation capacities of hDPSCs. Interestingly, significantly higher levels of expression of OCN and RUNX2 (for the osteogenic differentiation test), MAP-2 (for neurogenic differentiation test), and PPAR- $\gamma$ (for the adipogenic differentiation test) were detected in E8 (Fig. 6e) $(p<0.01)$.

\section{E8 promoted migration of hDPSCs}

Using a transwell test, representative images of hDPSCs cultured in both media at $6 \mathrm{~h}$ and $24 \mathrm{~h}$ are demonstrated in Fig. 7a, b. E8 increased cell migration numbers at $6 \mathrm{~h}$ $(p<0.01), 12 \mathrm{~h}(p<0.01)$, and $24 \mathrm{~h}(p<0.01)$ (Fig. 7c).

In the scratch assay, representative images of hDPSCs cultured in both media at $0 \mathrm{~h}, 24 \mathrm{~h}$, and $48 \mathrm{~h}$ were captured under microscopy (Fig. 8a-c). The scratch width was the same at the start between the two groups $(p>$ 0.05 ), and a clear motility difference was observed at
$24 \mathrm{~h}(p<0.01)$ and $48 \mathrm{~h}(p<0.01)$ (Fig. 8d). A more obvious narrowing was observed at $24 \mathrm{~h}$ using E8. After $48 \mathrm{~h}$ of incubation, the gaps in the E8 group were invisible, while in the SCM group they were not.

\section{Discussions}

Over the past decade, a substantial amount of research has focused interest on the need for the improvement of cell culture. In our study, hDPSCs were used to characterize and examine their properties. hDPSCs can be easily accessed and extracted from human third molars or deciduous teeth; however, as a type of highly differentiated stem cell, hDPSCs are commonly believed to be the least pluripotent among human DSCs. If hDPSCs could achieve satisfying proliferation and pluripotency performance in our serum-free culture environment, other human DSCs, such as periodontal ligament stem cells (PDLSCs), dental follicle stem cells (DFSCs) and dental epithelial stem cells

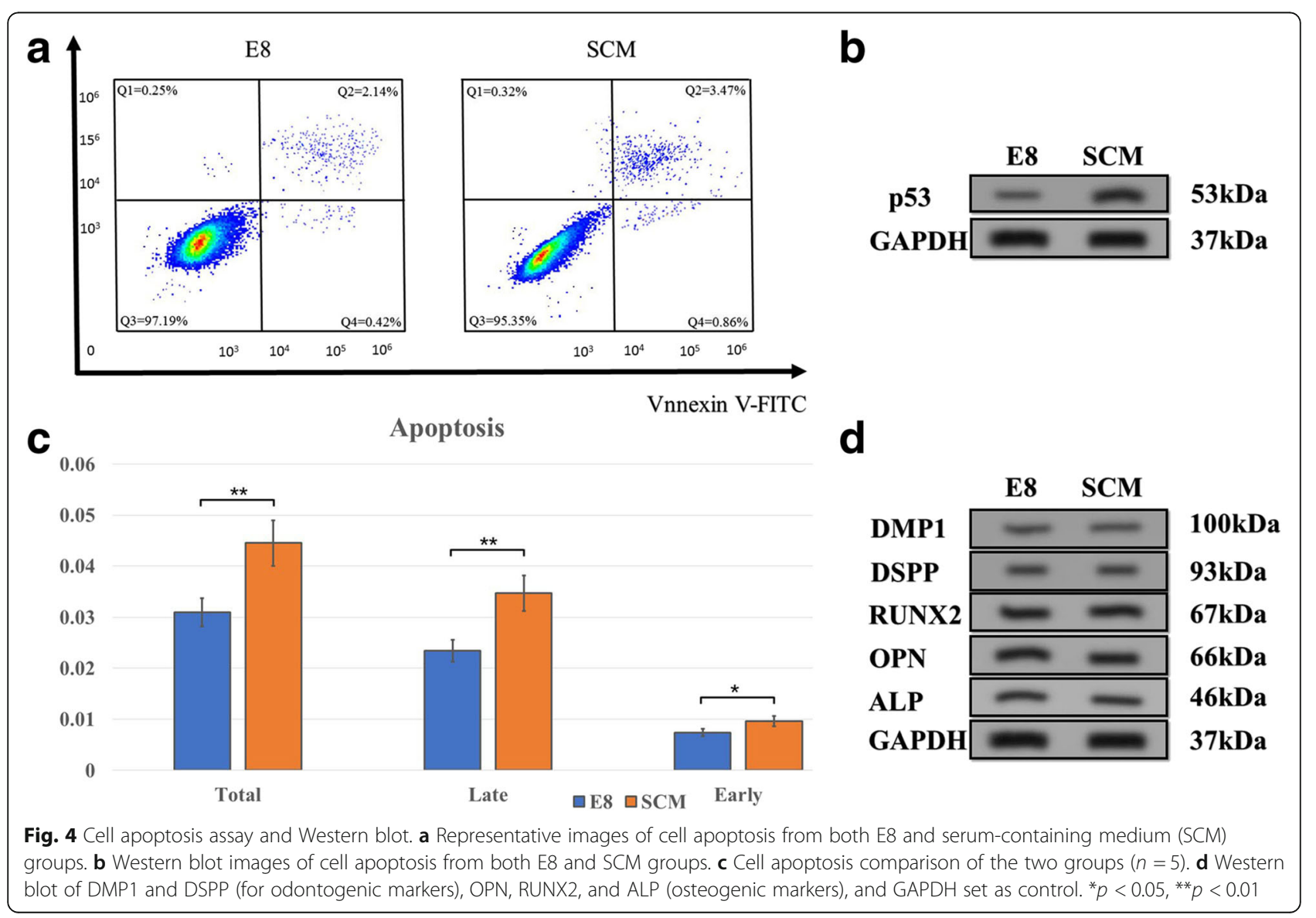




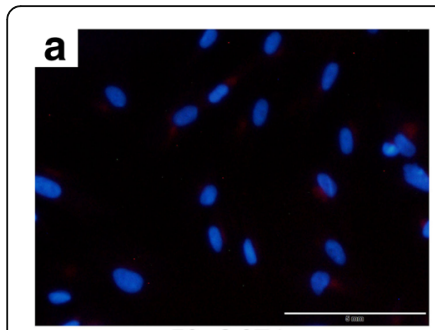

E8-OCT4

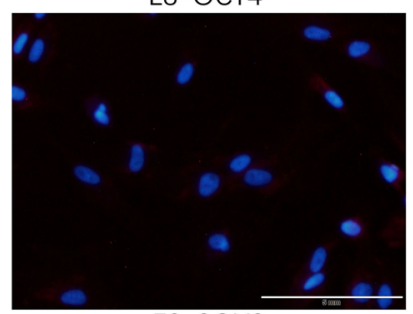

E8-SOX2
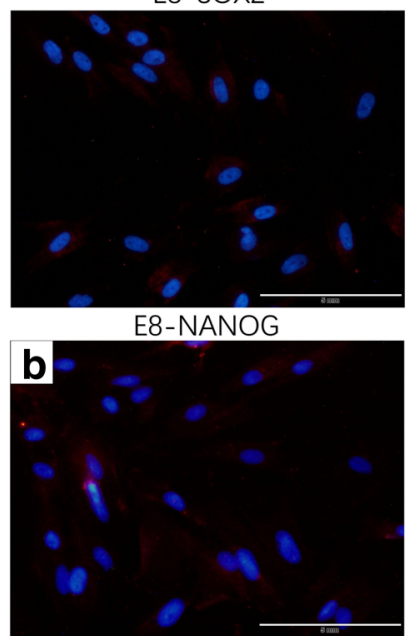

E8-DMP1

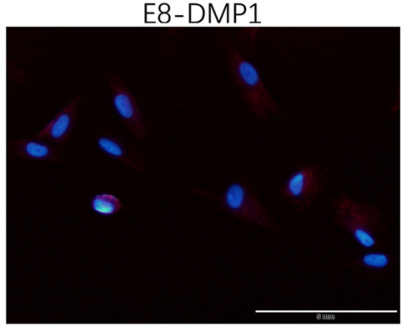

E8-DSP1-H

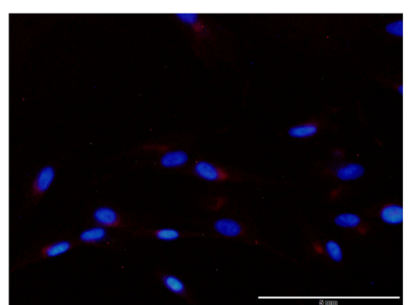

SCM-OCT4

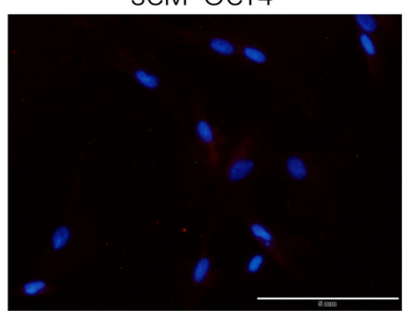

SCM-SOX2

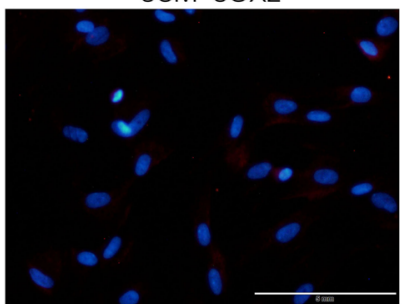

SCM-NANOG

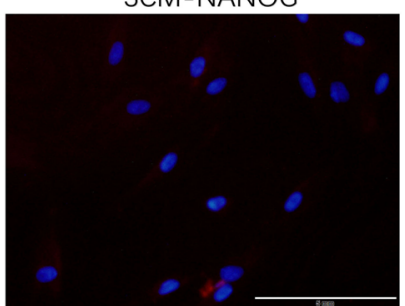

SCM-DMP1

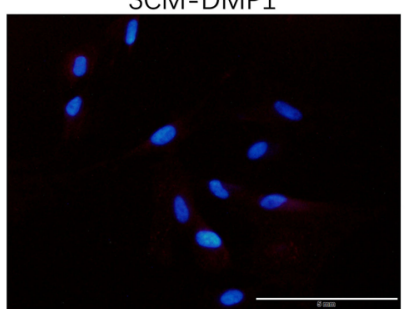

SCM-DSP1-H

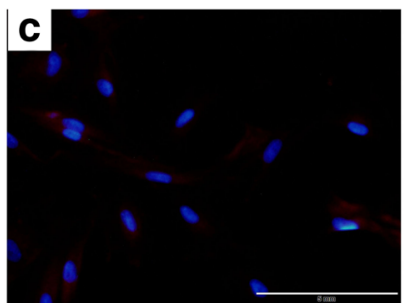

E8-p53

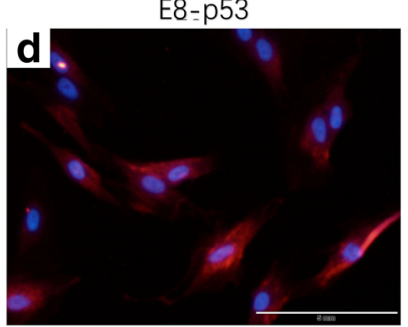

E8-OPN

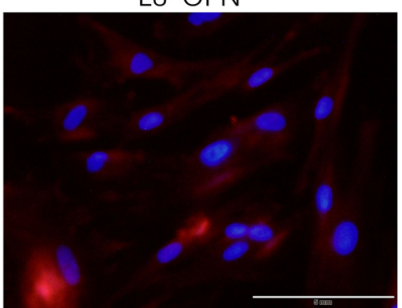

E8-OCN

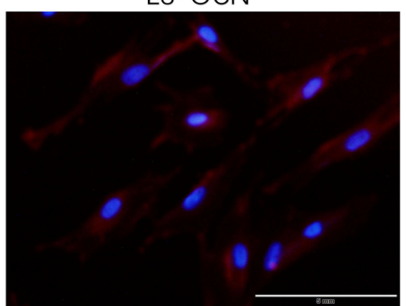

E8-BMP2

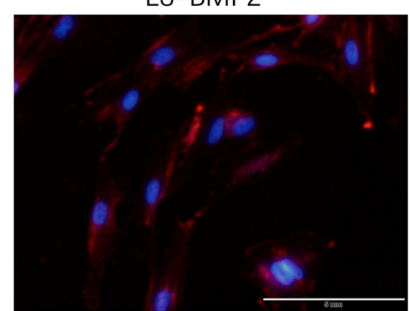

E8-RUNX2

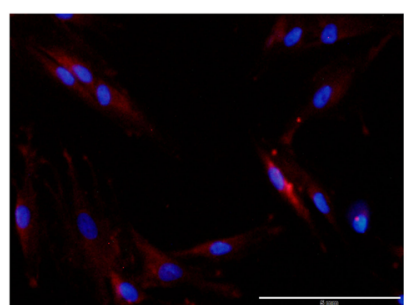

SCM-p53

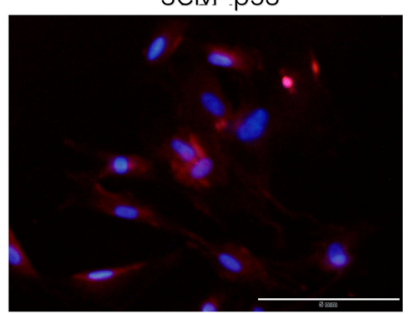

SCM-OPN

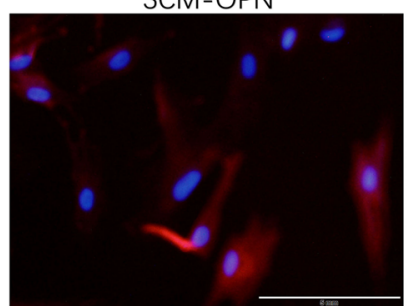

SCM-OCN

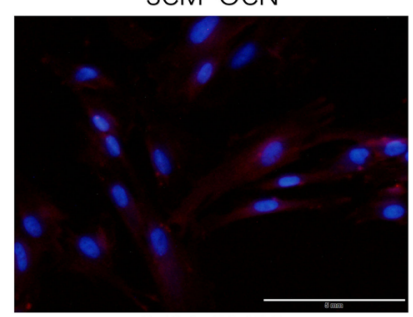

SCM-BMP2

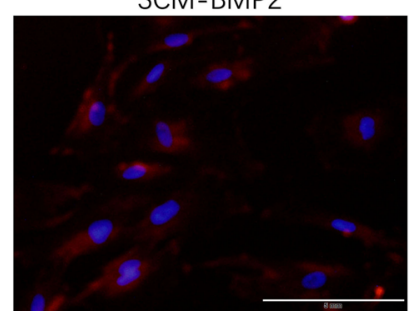

SCM-RUNX2

Fig. 5 Immunofluorescence of hDPSCs. a OCT4, SOX2, and NANOG for cell pluripotency. b DMP1 and DSP1-H for odontogenic tendency. $\mathbf{c}$ p53 images of cell apoptosis from both the E8 and serum-containing medium (SCM) groups. $\mathbf{d}$ OCN, OPN, RUNX2, and BMP2 for the

osteogenic tendency

(DESCs), might exhibit the same or better outcomes under the same culture conditions.

Although E8 was originally designed for iPSCs, the composition was shown to have multiple functions in stem cells, including in hDPSCs. FGF2 can regulate the Wnt signal pathway and its downstream signal via the PI3-K signal channel to maintain the undifferentiated state of hESCs and to maintain their self-renewal capacity $[32,33]$. Ascorbic acid is a kind of water-soluble vitamin which plays a critical role in the formation of collagen that can improve the cell proliferation. Insulin can induce the absorbance of both glucose and amino acids [34], and selenite supplementation of culture media is capable of restoring the antioxidative capacity of bone marrow MSCs and reducing intracellular reactive oxygen species (ROS) production and stress-related generation of micronuclei [35]. Activin/Nodal signaling through Smad2/3 activation is necessary to maintain the 

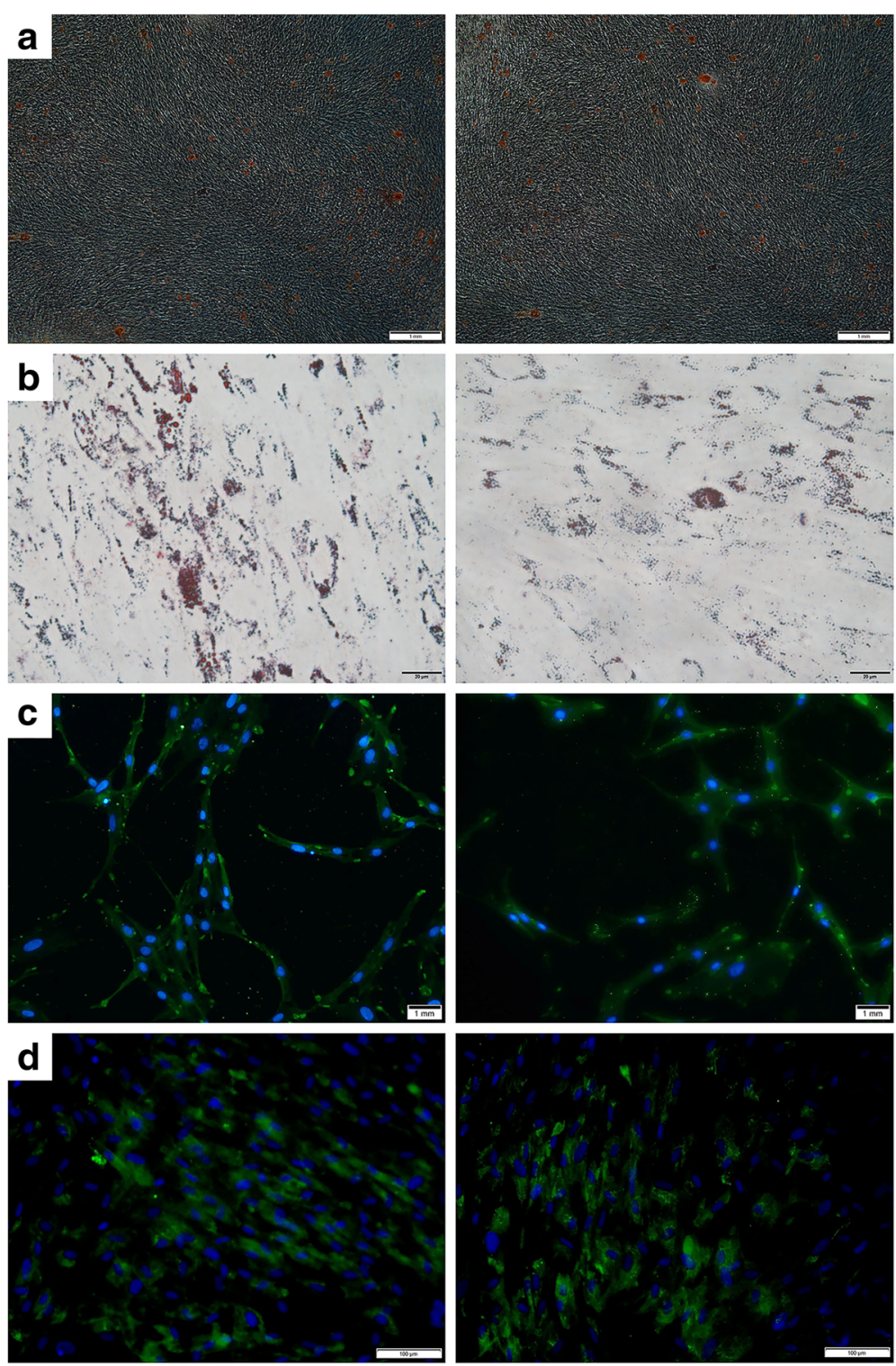

e

PCR

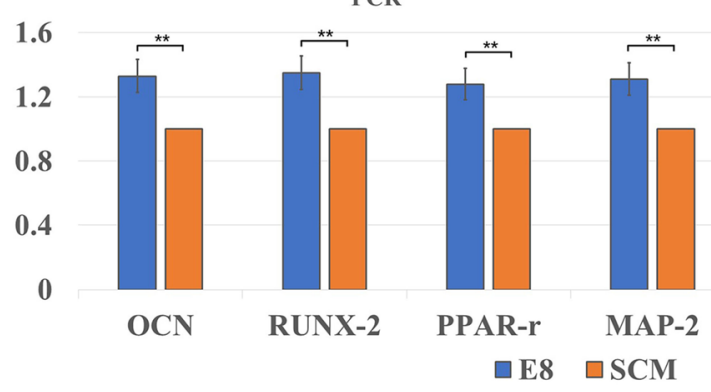

Fig. 6 Multi-differentiation analysis of hDPSCs. E8(left); SCM(right) a hDPSCs cultured in osteogenic medium for 15 days. b hDPSCs cultured in adipogenic medium for 15 days. c hDPSCs cultured in neurogenic medium for $3 \mathrm{~h}$. $\mathbf{d}$ hDPSCs cultured in chondrogenic medium for 15 days. e Real-time polymerase chain reaction (PCR) analysis of the multidifferentiation capacities of hDPSCs. Relative quantities were measured, and significantly higher levels of expressions of OCN and RUNX2 (for osteogenic differentiation), MAP-2 (for neurogenic differentiation), and PPAR- $\gamma$ (for adipogenic differentiation) were detected in E8 compared with serum-containing medium (SCM) $(n=5) .{ }^{*} p<0.05,{ }^{* *} p<0.01$ 


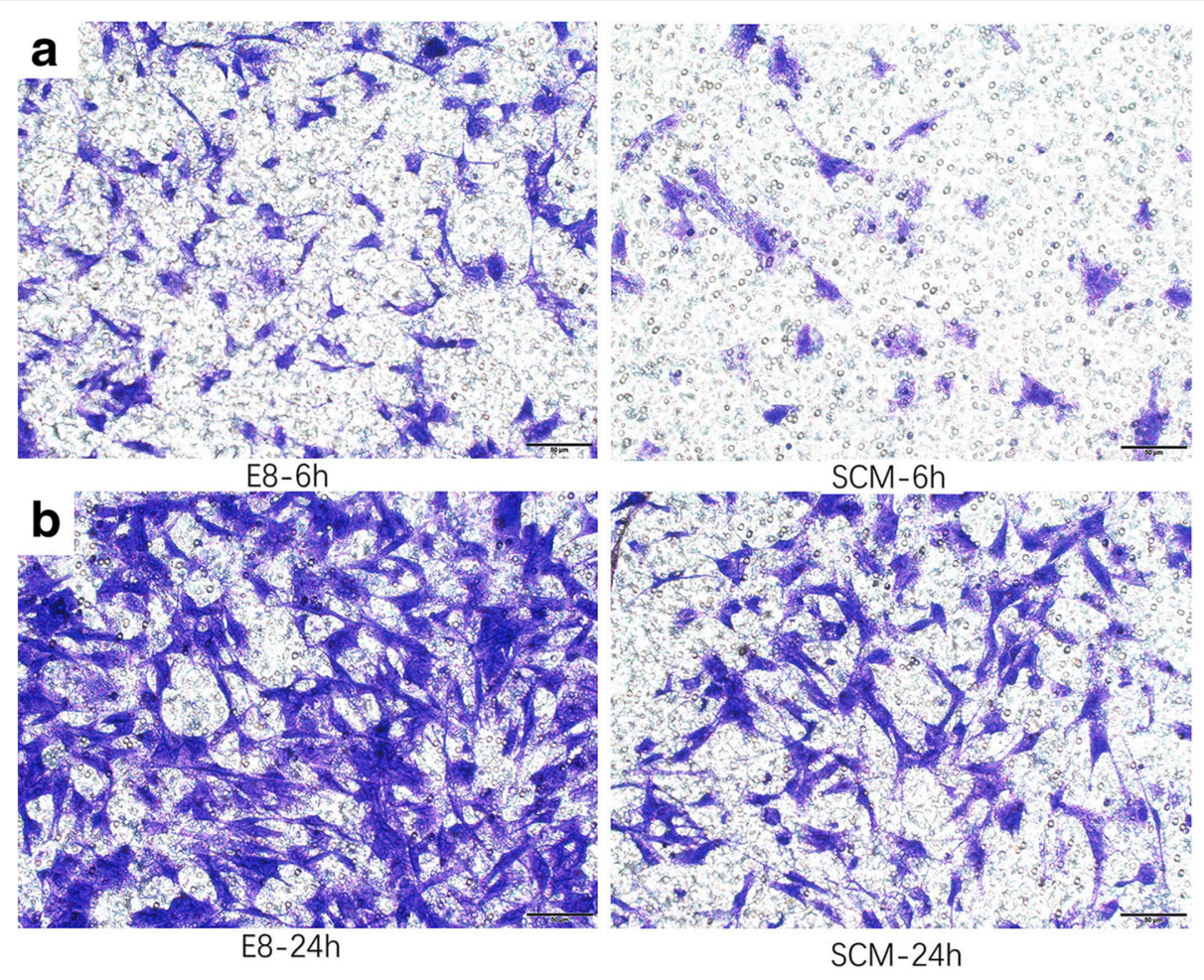

C

Transwell

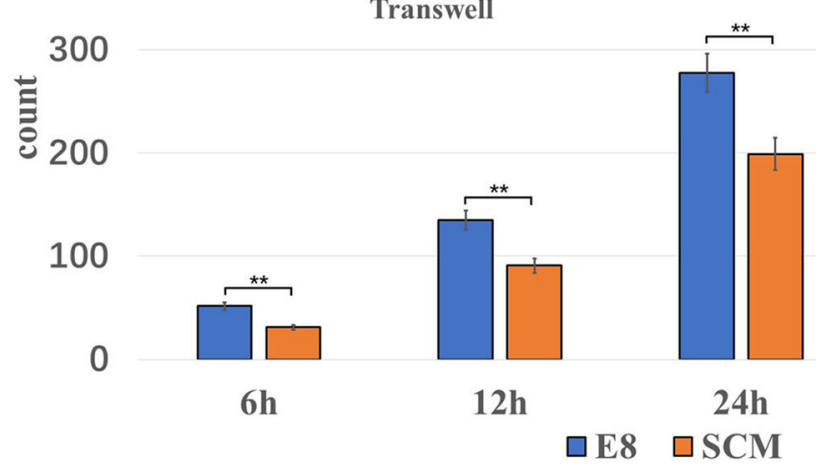

Fig. 7 Migration capacity analysis by transwell for hDPSCs. Representative fields of images from transwell test are shown, with visual comparisons on migrated cell numbers between E8 and serum-containing medium (SCM) at $\mathbf{a} 6 \mathrm{~h}$ and $\mathbf{b} 24 \mathrm{~h}$. c Statistical analysis of migrated cell numbers between E8 and SCM at 6 h, 12 h, and $24 \mathrm{~h}(n=5) .{ }^{*} p<0.05,{ }^{* *} p<0.01$

pluripotent status of hESCs [36, 37]. Other growth factors including platelet-derived growth factor (PDGF), basic (b)FGF, and epidermal growth factor (EGF) also play a key role in maintaining the proliferation rate and pluripotency of stem cells $[38,39]$. All the informed research into the functions of the signal pathways of growth factors gives us the foundation to use E8 medium in our experimental group. Additionally, E8 only contains eight essential factors [31] at a determined concentration, which is simple and convenient if researchers are willing to adjust the density of certain compositions, or to facilitate with other methods for further studies.
To eliminate variation, we used the same batch of hDPSCs for primary culture. In this way, although the cells were not purified, they can be considered to contain the same cell components and pluripotency. During CCK-8 analysis we detected that the OD value between E8 and SCM (both without cell culture) were different, so we used the difference in OD value between the media alone and the media cultured with cells to reduce the error caused by culture media. Hirata et al. [15] characterized and assessed cell proliferation and pluripotency under SFM conditions, but insulin-transferrin-selenium-X supplements alone were not enough, so they added embryotrophic factor to reach the same proliferation speed. Previous research has revealed 


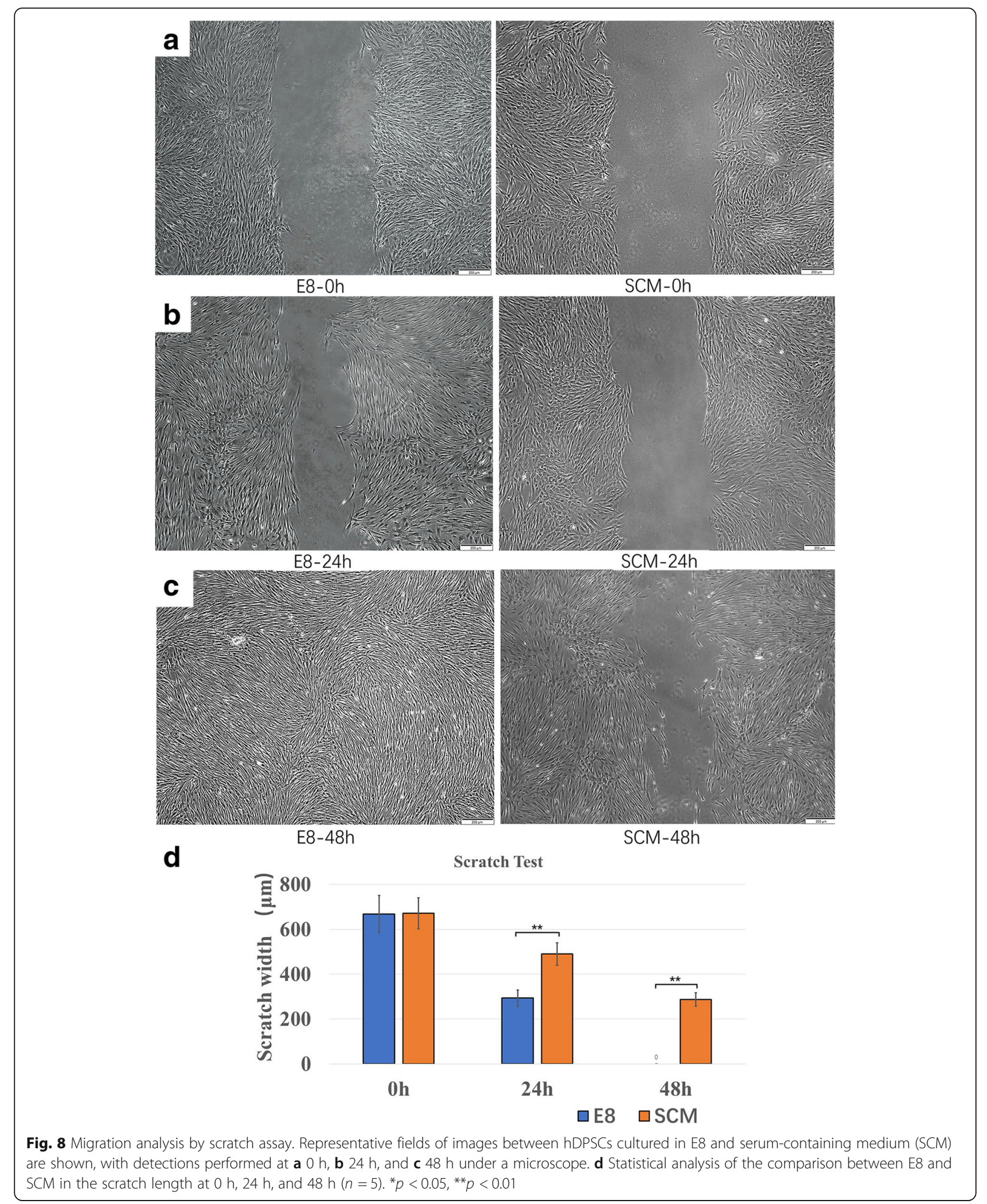


that ascorbic acid, a kind of water-soluble vitamin which is a part of the composition of E8, plays a critical role in the formation of collagen, and thus enhances cell attachment [34]. This might explain the reason why the E8 group reached a high speed of expansion faster. Cell migration analysis showed that E8-cultured hDPSCs also had better mobility, indicating that our serum-free culture condition performed better in maintaining cytoactivity. Nevertheless, further studies should be performed to exploit the specific mechanism of this condition.

Previous studies demonstrated that hDPSCs present similar cell surface markers to MSCs [40] and, under certain conditions, hDPSCs can be induced to adipose tissue, osseous tissue, and nerve tissue [41]. The immunofluorescence and Western blot results suggested that no significant differences in pluripotency were observed, indicating that both groups maintained the same pluripotency under conditions without stimuli. However, induced differentiation results showed that hDPSCs cultured in E8 presented higher levels of expression of OCN, RUNX2, and PPAR- $\gamma$, indicating that in the case of irritation E8 is more efficient for maintaining multipotentiality towards osteogenic and adipogenic tissues for hDPSCs. Earlier studies displayed similar outcomes, and some also revealed the potential to be induced to other cell lineages. Harada et al. [42] compared cell proliferation, cell morphology, and gene expression change between SCM and SFM, but they did not detect induced differentiation. Ishkitiev et al. [26] successfully induced DPSCs to the hepatic lineage under SFM conditions. However, they did not induce these cells into other lineages. Okada et al. [43] also successfully induced hDPSCs to the hepatic lineage with hydrogen sulfide, and showed the same or higher performance. Ishkitiev et al. [44] induced hDPSCs to differentiate into the pancreatic cell lineage under serum-free conditions. As stem cells extracted from dental tissues, hDPSCs should demonstrate advantages in dentistry and bio-root regeneration in the near future. In 2010, Huang et al. [45] showed that DPSCs were capable of forming vascularized pulp/dentin-like tissue in an empty human root canal when seeded onto a polylacticco-glycolic acid (PLGA) scaffold. This study, consistent with previous research, supported the possibility of using hDPSCs to establish patient-specific or industrializedgrade cell lines for stem cell therapy.

Al-Saqi et al. [46] applied Mesencult-XF as their serum-free medium to analyze its maintenance of pluripotency and growth towards adipose-derived MSCs. In a pre-experiment, we attempted to use Mesencult-XF to culture hDPSCs. Although cells cultured in Mesencult-XF displayed satisfying growth, we observed cell attachment problems; however, this phenomenon might be due to a difference in the applied culturing process. Furthermore, Mesencult-XF is relatively costly, and clinical cultures consume lots of media. Our work here, for the first time, applied E8 as a chemically defined, serum-free medium for hDPSC culture and analyzed its performance. However, most of our work was based on short-term culture comparison, and long-term culture data are still a requirement for further exploration. Although serum-free medium was applied during the cell culture and incubation, the use of FBS for the isolation of a primary cell culture is still indispensable and there are no statistical data suggesting how this application will affect cell proliferation and pluripotency [30].

\section{Conclusions}

In conclusion, our study presents a novel application of the E8 medium in hDPSC culture, and shows that E8 is practical for the proliferation and differentiation of hDPSCs to reduce the effects of the problems caused by FBS as described above. E8 possesses a simple composition for the convenience of further downstream processing and improvement, which makes it practical to us as a primary culture medium for the establishment of DSC banking. Nevertheless, many challenges and obstacles still need to be resolved for its ultimate use in the clinic, and the mechanisms and functions of growth factors in maintaining hDSPC potency and proliferation should be fully analyzed and understood to achieve the optimum culture environment. More effective factors are needed, and deeper studies are still required, for improvement of the serum-free culture conditions. Other issues, such as the application of FBS in cell passaging and cryopreservation should also be resolved to establish a mature SFM culture system which can meet the DSC banking standards.

\section{Abbreviations}

BrdU: Bromodeoxyuridine; CCK-8: Cell counting kit; CFU-F: Colony-forming unit fibroblast; DMEM: Dulbecco's modified Eagle's medium; DPSC: Dental pulp stem cell; DSC: Dental stem cell; FBS: Fetal bovine serum; FGF: Fibroblast growth factor; FITC: Fluorescein isothiocyanate; hDPSC: Human dental pulp stem cell; hESC: Human embryonic stem cell; hPSC: Human pluripotent stem cell; MSC: Mesenchymal stem cell; OD: Optical density; P: Passage; PCR: Polymerase chain reaction; PE: Phycoerythrin; PI: Propidium iodide; SCM: Serum-containing medium; SFM: Serum-free medium; TGF: Transforming growth factor

\section{Funding}

This study was supported by the National Key Research and Development Program of China (2017YFA0104800 and 2016YFC1101400), the Nature Science Foundation of China (31470947), the Key Research and Development Program of Sichuan Province (2017SZ0031), and the College student's Platform for Innovation and Entrepreneurship Training Program of China (2082404131053).

\section{Availability of data and materials}

All data generated and/or analyzed during this study are available from the corresponding author upon reasonable request.

\section{Authors' contributions}

WG and WT designed the experiments; JX performed the experiments and wrote the paper with the assistance of DY. DY collected and analyzed the data; QL revised and checked the language use and data. All authors read and approved the final manuscript.

Ethics approval and consent to participate Not applicable. 


\section{Competing interests}

The authors declare that they have no competing interests.

\section{Publisher's Note}

Springer Nature remains neutral with regard to jurisdictional claims in published maps and institutional affiliations.

\section{Author details}

'State Key Laboratory of Oral Diseases \& National Clinical Research Center for Oral Diseases \& National Engineering, Chengdu, China. ${ }^{2}$ Laboratory for Oral Regenerative Medicine, West China Hospital of Stomatology, Sichuan University, Chengdu 610041, China. ${ }^{3}$ Department of Oral and Maxillofacial Surgery, West China Hospital of Stomatology, Sichuan University, No.14, 3rd Section, Renmin South Road, Chengdu 610041, People's Republic of China. ${ }^{4}$ Department of Pediatric Dentistry, West China School of Stomatology, Sichuan University, Chengdu 610041, People's Republic of China. ${ }^{5}$ Department of Prosthodontics, West China Hospital of Stomatology, Sichuan University, Chengdu 610041, China.

Received: 4 March 2018 Revised: 3 June 2018 Accepted: 13 June 2018 Published online: 11 July 2018

\section{References}

1. Kalista T, Freeman HA, Behr B, Pera RR, Scott CT. Donation of embryos for human development and stem cell research. Cell Stem Cell. 2011:8:360-2.

2. Dever DP, Bak RO, Reinisch A, Camarena J, Washington G, Nicolas CE, et al. CRISPR/Cas9 beta-globin gene targeting in human haematopoietic stem cells. Nature. 2016;539:384-9.

3. Blodgett DM, Nowosielska A, Afik S, Pechhold S, Cura AJ, Kennedy NJ, et al. Novel observations from next-generation RNA sequencing of highly purified human adult and fetal islet cell subsets. Diabetes. 2015;64:3172-81.

4. Karantalis V, Hare JM. Use of mesenchymal stem cells for therapy of cardiac disease. Circ Res. 2015;116:1413-30.

5. Daley GQ, Scadden DT. Prospects for stem cell-based therapy. Cell. 2008; 132:544-8

6. Taylor CJ, Bolton EM, Pocock S, Sharples LD, Pedersen RA, Bradley JA. Banking on human embryonic stem cells: estimating the number of donor cell lines needed for HLA matching. Lancet. 2005;366:2019-25.

7. Onder T, Daley GQ. New lessons learned from disease modeling with induced pluripotent stem cells. Curr Opin Genet Dev. 2012;22:500-8.

8. Lindemann D, Werle SB, Steffens D, Garcia-Godoy F, Pranke P, Casagrande L. Effects of cryopreservation on the characteristics of dental pulp stem cells of intact deciduous teeth. Arch Oral Biol. 2014:59:970-6.

9. Chen KG, Mallon BS, McKay RD, Robey PG. Human pluripotent stem cell culture: considerations for maintenance, expansion, and therapeutics. Cell Stem Cell. 2014;14:13-26.

10. Julavijitphong $\mathrm{S}$, Wichitwiengrat $\mathrm{S}$, Tirawanchai $\mathrm{N}$, Ruangvutilert $\mathrm{P}$, Vantanasiri C, Phermthai T. A xeno-free culture method that enhances Wharton's jelly mesenchymal stromal cell culture efficiency over traditional animal serum-supplemented cultures. Cytotherapy. 2014;16:683-91.

11. Halme DG, Kessler DA. FDA regulation of stem-cell-based therapies. N Engl J Med. 2006;355:1730-5.

12. Thirumala S, Goebel WS, Woods EJ. Manufacturing and banking of mesenchymal stem cells. Expert Opin Biol Ther. 2013;13:673-91.

13. Baker DE, Harrison NJ, Maltby E, Smith K, Moore HD, Shaw PJ, et al. Adaptation to culture of human embryonic stem cells and oncogenesis in vivo. Nat Biotechnol. 2007;25:207-15.

14. Hayashi I, Sato GH. Replacement of serum by hormones permits growth of cells in a defined medium. Nature. 1976;259:132-4.

15. Hirata TM, Ishkitiev N, Yaegaki K, Calenic B, Ishikawa H, Nakahara T, et al. Expression of multiple stem cell markers in dental pulp cells cultured in serum-free media. J Endod. 2010;36:1139-44.

16. Bonnamain $V$, Thinard R, Sergent-Tanguy S, Huet P, Bienvenu G, Naveilhan $P$, et al. Human dental pulp stem cells cultured in serum-free supplemented medium. Front Physiol. 2013;4:1-9.

17. Chen TH, Chen WM, Hsu KH, Kuo CD, Hung SC. Sodium butyrate activates ERK to regulate differentiation of mesenchymal stem cells. Biochem Biophys Res Commun. 2007;355:913-8.

18. Oshimori N, Fuchs $\mathrm{E}$. The harmonies played by TGF-beta in stem cell biology. Cell Stem Cell. 2012;11:751-64.
19. Kratchmarova I, Blagoev B, Haack-Sorensen M. Mechanism of divergent growth factor effects in mesenchymal stem cell differentiation. Science. 2005;308:1472-7.

20. Xiao L, Yuan $X$, Sharkis SJ. Activin A maintains self-renewal and regulates fibroblast growth factor, Wnt, and bone morphogenic protein pathways in human embryonic stem cells. Stem Cells. 2006;24:1476-86.

21. Calne RY. Prospects for cell-based therapy. Transplant Proc. 2004;36: 3183-7.

22. Mooney DJ, Powell C, Piana J, Rutherford B. Engineering dental pulp-like tissue in vitro. Biotechnol Prog. 1996;12:865-8.

23. Gronthos $\mathbf{S}$ et al. Stem cell properties of human dental pulp stem cells. J Dental Res. 2002;81:531-5.

24. Miura M, Gronthos S, Zhao M, Lu B, Fisher LW, Robey PG, et al. SHED: stem cells from human exfoliated deciduous teeth. Proc Natl Acad Sci U S A. 2003:100:5807-12.

25. Seo B-M, Miura M, Gronthos S, Mark Bartold P, Batouli S, Brahim J, et al. Investigation of multipotent postnatal stem cells from human periodontal ligament. Lancet. 2004;364:149-55.

26. Ishkitiev N, Yaegaki K, Imai T, Tanaka T, Nakahara T, Ishikawa H, et al. Highpurity hepatic lineage differentiated from dental pulp stem cells in serumfree medium. J Endod. 2012:38:475-80.

27. Hilkens P, Meschi N, Lambrechts P, Bronckaers A, Lambrichts I. Dental stem cells in pulp regeneration: near future or long road ahead? Stem Cells Dev. 2015;24:1610-22.

28. Temmerman L, Beele H, Dermaut LR, Van Maele G, De Pauw GA. Influence of cryopreservation on the pulpal tissue of immature third molars in vitro. Cell Tissue Bank. 2010;11:281-9.

29. Coburn RJ, Henriques BL, Francis LE. Development of an experimental tooth bank using DEEP freeze and tissue culture techniques. J Oral Ther Pharmacol. 1966;2:445.

30. YHHe a. Dental stem cells and tooth banking for regenerative medicine. J Exp Clin Med. 2010;2:111-7.

31. Chen G, Gulbranson DR, Hou Z, Bolin JM, Ruotti V, Probasco MD, et al. Chemically defined conditions for human iPSC derivation and culture. Nat Methods. 2011:8:424-9.

32. $\mathrm{Ng} \mathrm{F}$, Boucher $\mathrm{S}$, Koh S, Sastry KS, Chase L, Lakshmipathy U, et al. PDGF, TGF-beta, and FGF signaling is important for differentiation and growth of mesenchymal stem cells (MSCs): transcriptional profiling can identify markers and signaling pathways important in differentiation of MSCs into adipogenic, chondrogenic, and osteogenic lineages. Blood. 2008; 112:295-307

33. Xu RH, Peck RM, Li DS, Feng X, Ludwig T, Thomson JA. Basic FGF and suppression of BMP signaling sustain undifferentiated proliferation of human ES cells. Nat Methods. 2005;2:185-90.

34. Harada S, Matsumoto T, Ogata E. Role of ascorbic-acid in the regulation of proliferation in osteoblast-like mc3t3-e1 cells. J Bone Miner Res. 1991;6:903-8.

35. Ebert $U$, Zeck, et al. Selenium supplementation restores the antioxidative capacity and prevents cell damage in bone marrow stromal cells in vitro. Stem Cells. 2006;24:1226-35.

36. Chen G, Hou Z, Gulbranson DR, Thomson JA. Actin-myosin contractility is responsible for the reduced viability of dissociated human embryonic stem cells. Cell Stem Cell. 2010;7:240-8.

37. Vallier L, Alexander M, Pedersen RA. Activin/nodal and FGF pathways cooperate to maintain pluripotency of human embryonic stem cells. J Cell Sci. 2005;118:4495-509.

38. Gronthos S, Simmons PJ. The growth-factor requirements of stro-1-positive human bone-marrow stromal precursors under serum-deprived conditions in-vitro. Blood. 1995;85:929-40.

39. Wang X, Zheng F, Liu O, Zheng S, Liu Y, Wang Y, et al. Epidermal growth factor can optimize a serum-free culture system for bone marrow stem cell proliferation in a miniature pig model. In Vitro Cell Dev Biol Anim. 2013;49:815-25.

40. Atari M, Gil-Recio C, Fabregat M, Garcia-Fernandez D, Barajas M, Carrasco MA, et al. Dental pulp of the third molar: a new source of pluripotent-like stem cells. J Cell Sci. 2012;125:3343-56.

41. Kawashima N. Characterisation of dental pulp stem cells: a new horizon for tissue regeneration? Arch Oral Biol. 2012;57:1439-58.

42. Harada K, Kawai S, Xu W-a, Xu I, Sonomoto M, Shinonaga Y, et al. Alterations in deciduous dental pulp cells cultured with serum-free medium. J Hard Tissue Biol. 2015;24:17-22. 
43. Okada M, Ishkitiev N, Yaegaki K, Imai T, Tanaka T, Fukuda M, et al. Hydrogen sulphide increases hepatic differentiation of human tooth pulp stem cells compared with human bone marrow stem cells. Int Endod J. 2014;47:1142-50.

44. Ishkitiev N, Yaegaki K, Kozhuharova A, Tanaka T, Okada M, Mitev V, et al. Pancreatic differentiation of human dental pulp CD117(+) stem cells. Regen Med. 2013:8:597-612.

45. Huang GTJ, Yamaza T, Shea LD, Djouad F, Kuhn NZ, Tuan RS, et al. Stem/ progenitor cell-mediated de novo regeneration of dental pulp with newly deposited continuous layer of dentin in an in vivo model. Tissue Eng A. 2010;16:605-15.

46. Al-Saqi SH, Saliem M, Asikainen S, Quezada HC, Ekblad A, Hovatta O, et al. Defined serum-free media for in vitro expansion of adipose-derived mesenchymal stem cells. Cytotherapy. 2014;16:915-26.

- fast, convenient online submission

- thorough peer review by experienced researchers in your field

- rapid publication on acceptance

- support for research data, including large and complex data types

- gold Open Access which fosters wider collaboration and increased citations

- maximum visibility for your research: over $100 \mathrm{M}$ website views per year 